\title{
An Empirical Analysis of Territorial Encroachment Within Franchised and Company-Owned Branded Chains
}

\author{
Arturs Kalnins \\ Marshall School of Business, Management and Organization Department (BRI306), University of Southern California, \\ Los Angeles, California 90089-0808, kalnins@marshall.usc.edu
}

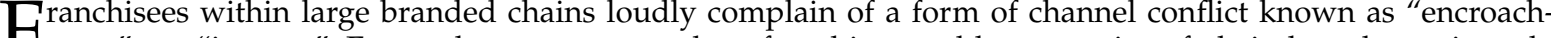
F ment" or "impact." Encroachment occurs when franchisors add new units of their brand proximately to their franchisees' existing units. Franchisees claim that their revenues have substantially decreased as a result of encroaching same-brand entry. The topic of encroachment has not only dominated franchisee association agendas and trade journal headlines but has also become a hot topic for politicians and policymakers. Yet, until now, evidence of encroachment has been strictly anecdotal. This paper provides the first systematic evidence of encroachment. Using revenue data from the Texas lodging industry in the 1990s, I find that when franchisors approve new same-brand units in the vicinity of incumbent units, these new units cannibalize the incumbents' revenues. In contrast to the result for franchisors, the addition of a new unit by company-owned brands in the vicinity of same-brand units is associated with an increase in the incumbents' revenues. This contrast suggests that encroaching behavior is caused by incentives that result from the governance form of franchising and is not simply an outcome that accompanies all expansion. This finding informs theory on governance forms and exclusive territories. Implications for practitioners and policy are also discussed.
\end{abstract}

Key words: channels of distribution; franchising; encroachment; cannibalization; market entry

History: This paper was received September 19, 2003, and was with author 3 months for 1 revision; processed

by Eugene Anderson.

The governance form of business format franchising is common in the retail and service sectors, particularly in the lodging and fast-food industries. In typical business format franchising contracts, the franchisee receives the right to use a franchisor's brand name and business plan in exchange for the payment of an upfront fee and a sales royalty. Over the last several decades, sales through business format franchised chains have grown from a negligible value to about $3.5 \%$ of the United States GDP, or to about $25 \%$ of all franchising in the nation (Lafontaine and Shaw 1999). Franchisors of established brands have fueled much of this growth by adding new units (sales locations) in markets where units affiliated with their brands already operate. As a result, franchisees of the existing units complain of a form of channel conflict known as "encroachment" or "impact." Franchisors are said to be encroaching on the incumbent franchisees' units by allowing other franchisees to operate new samebrand units in their vicinity. The incumbent franchisees claim that these new units cannibalize their revenues.
Encroachment has been called the "most explosive issue today in the franchising world" (Sheridan and Gillespie 1995, p. 64) and has consistently dominated agendas at franchisee conventions (Khanna and Ganot 1995, p. 13). In 1995, the Cornell Hotel and Restaurant Administration Quarterly even devoted a special journal issue to encroachment. Despite the extensive attention, the economic magnitude of this important and controversial phenomenon has not been systematically quantified. I begin to fill this gap-at least for one industry and geographic region-by estimating the effect of new units on revenues of proximate same-brand units within the ten largest hotel chains in the state of Texas.

Encroachment has become even more worthy of rigorous quantitative analysis because extensive lobbying efforts have convinced many policymakers that franchisees should be legally protected from encroachment. Legislative and judicial activity with this aim has placed policymakers in the unusual position of defending and even creating exclusive territories for incumbent retailers, a practice often con- 
sidered anticompetitive (Coughlan et al. 2000, Dutta et al. 1999, Blair and Lafontaine 2002). The strongest antiencroachment policy currently in place is the Iowa Franchise Act of $1992 .{ }^{1}$ The initial version of this act protected franchisees from encroachment by designating a three-mile radius around their incumbent units as an exclusive territory (Blair and Lafontaine 2002, Footnote 7). At a national level, the Small Business Franchise Act (HR 3308) was introduced in the U.S. Congress in 1999. If passed, this bill would give franchisees a right of first refusal for the ownership of any new units that might cannibalize their revenues. Franchisees also received a short-lived victory in the courts in 1991. The court ruled that, despite the lack of any contractual territorial exclusivity, the franchisor could be held liable if the franchisee lost revenues to a new same-brand unit nearby (Scheck v. Burger King Corp., 756 F. Supp. 543; S.D. Fla. 1991). This ruling was overturned in 1996.

Not all multiunit firms in industries such as fast food or hotels use franchising, however. Some firms that possess brand names are "company owned," meaning that they are vertically integrated into the ownership and operation of their individual units. A company-owned multiunit firm, much like a franchisor, may locate new units in such a way that cannibalizes revenues of incumbents. If same-brand entry decreases the revenues of proximate units within franchised chains, I would only conclude that there was a noteworthy encroachment effect if the same relationship did not hold among the units of company-owned firms.

I analyzed a large panel data set of quarterly revenues between 1990 and 1999 of all hotels operating in Texas affiliated with the state's ten largest brands. This data set allows a direct comparison of encroachment effects within franchised chains and within company-owned chains because both forms exist among these ten chains. The La Quinta and Motel 6 brands are almost completely company-owned, while the others are almost completely franchised. The eight large franchised chains studied here are Best Western, Comfort Inn, Days Inn, Econolodge, Hampton Inn, Holiday Inn, Ramada, and Super 8. I estimated fixedeffects regressions with temporal and location-specific intercepts to assess not only the effect of encroachment (proximate same-brand entry) but also its opposite (same-brand exit). If same-brand entry decreases incumbents' revenues, then same-brand exit is likely to increase those revenues.

The paper is organized as follows. In §2, I describe institutional regularities of franchising and the lodg-

\footnotetext{
${ }^{1}$ Hawaii, Indiana, Minnesota, and Washington also have franchise laws with antiencroachment provisions. These provisions are much less extensive than those in the Iowa statute (Blair and Lafontaine 2002, Footnote 60)
}

ing industry. I also present theoretical arguments that explain the basis of encroachment effects. Section 3 describes the Texas hotel data in detail. Section 4 describes the empirical methodology and the measurement of all variables. Section 5 provides a detailed description of empirical results and extensive robustness tests. Section 6 presents a concluding discussion along with implications for research, practitioners, and policymakers.

\section{Background}

\subsection{Institutional Regularities of Business Format Franchising and the Lodging Industry}

In this section, I briefly describe four institutional regularities directly relevant to an analysis of encroachment. First, as mentioned above, company-owned brands co-exist with franchised brands in the lodging industry. This regularity is surprising because transactions cost explanations of franchising (Williamson 1991) and of the organization of distribution channels (Anderson 1985), as well as agency-theoretic explanations of franchising (e.g., Lafontaine 1992, Lal 1990) predict that all firms engaging in the same transaction should choose the same form of governance. Yet we observe chains such as Motel 6 and Super 8 using company ownership and franchising, respectively, even though the two brands appear to engage in transactions almost identical with respect to frequency, uncertainty, and asset specificity. Further, with the exception of Motel 6 at the very end of the study period, the lodging chains in this study do not use dual distribution. They are largely committed to either franchising or company ownership and do not choose between the two governance forms on a unitby-unit basis. $^{2}$

A second important institutional regularity is that individual hotels commonly convert from one brand to another (Khanna and Ganot 1995, Conlin 2003), a behavior not often observed in other industries that have a substantial amount of franchising. Conversions by proximate units from other brands to an incumbent's brand allow an analysis of encroachment effects on the incumbent's revenues without any confounding effect of increased supply.

Third, the large, established franchised chains typically do not provide exclusive territories to franchisees (Azoulay and Shane 2001). Of the franchised chains in this study, only Super 8 offered territorial protec-

\footnotetext{
${ }^{2}$ In contrast to lodging, dual distribution is very common among fast food chains. Pizza Hut and Wendy's company-owned 53\% and 39\%, respectively, of their units in Texas in 1995 (Kalnins and Lafontaine 2004). Brickley and Dark (1987) presented evidence that restaurant franchisors choose between the governance forms on a unit-by-unit basis based on ease of monitoring each unit. Yin and Zajac (2004) suggest that the choice be made on the complexity of the operations at the unit.
} 
tion for its franchisees throughout the 1990s (Patel and Corgel 1995, Worcester 1998). Super 8 negotiated a distance radius with each franchisee, typically between one and seven miles, within which the franchisor would refrain from adding new same-brand units. The Cendant corporation, owner of Day's Inn, Ramada, and Super 8, began to offer similar protection across all its brands in late 1998 (Worcester 1998). Throughout the 1990s, all franchisors in this study had "notification distances" within which they notified incumbent franchisees of plans to open a new same-brand unit using another franchisee. This distance is typically 15 miles or the third closest same-brand unit (Patel and Corgel 1995). Franchisees could then petition against the development of the new unit, but burden of proof regarding encroachment typically has been placed on the franchisee (Khanna and Ganot 1995).

Fourth, $90 \%$ of franchisors (and seven of the eight franchised chains studied here) collect an upfront fixed fee and sales royalty from franchisees (Lafontaine 1992). Best Western charges a fixed fee and an annual room-count fee. While theory often emphasizes the role of a fixed fee in the extraction of all rents from downstream retailers, Lafontaine and Shaw (1999) state that on average fixed fees represent only $8 \%$ of all payments from franchisees to franchisors, while the sales royalty accounts for the vast remainder. Further, Kaufmann and Lafontaine (1994) and Michael and Moore (1995) present empirical evidence that franchisors are unable to extract all rents via a fixed fee (see also Villas-Boas 1998, pp. 166-167, on this point). As will be discussed below, a reliance on the sales royalty and the inability to extract all rents via a fixed fee gives franchisors more incentive than company-owned firms to encroach on their existing properties.

\subsection{Relevant Literatures}

Industrial organization theory has long predicted that prices and revenues of a market's incumbent firms will decrease if new firms enter that market. This proposition has received substantial empirical support. For example, Joskow et al. (1994) found that entry reduced airline fares and increased overall output (but reduced output of incumbents) and exit increased fares and reduced overall output. The prediction that entry causes revenue losses for incumbents is easily extended to the case of sales locations differentiated by brand. Entry of a branded unit will likely cause greater revenue losses for samebrand incumbents than for other-brand units because customers likely view the two same-brand units as the closest substitutes, differentiated only geographically. Consistent with this premise, recent studies have found pricing patterns consistent with intrabrand competition within the large branded lodging chains
(Conlin 2003) and fast-food chains (Kalnins 2003, Thomadsen 2004). In addition, Ingram and Baum (1997) found that a chain's hotels in Manhattan were less likely to survive when the chain operated more units there.

The above arguments, while certainly suggestive of encroachment, do not predict any differences in behavior between company-owned and franchised chains. Below, I discuss two theoretical arguments that imply franchisors are more likely than companyowned firms to make entry choices that cannibalize revenues of same-brand incumbents.

The first argument implying encroachment is that franchising is a strategic device; use of the governance form allows firms to credibly commit to "strategic toughness" toward rivals. In particular, upstream firms divisionalize (i.e., franchise) to commit to a higher level of output (Baye et al. 1996). The mechanism at the core of Baye et al.'s argument is that firms generate intrabrand quantity competition by divisionalizing, thus securing greater market share for the brand overall. ${ }^{3}$ This logic implies that the behavior of franchisors and company-owned firms will differ. Consider a case where a market consists of two firms, one committed to each of the two governance forms. The company-owned firm will remain a single entity, while the franchisor will create divisions until inhibited from doing so by fixed divisionalization costs. Thus, the franchisor will capture greater market share. Assuming that divisions are opened sequentially, however, each incumbent division will lose revenues as the new divisions begin operations. The companyowned firm will locate additional units only in new markets, implying that revenues at existing locations will not go down when new units are added.

A second argument implying a greater likelihood of encroachment within franchised chains is based on the institutional regularity that business format franchisors receive a sales royalty from franchisees, rather than a profit royalty, and cannot extract remaining rents via a fixed fee. Kaufmann and Rangan (1990) modeled the resulting conflicts, which do not in any way depend on active intrabrand competition among franchisees. Franchisors have incentives to approve new units as long as the revenues at the new location are greater than the resulting revenue losses at existing locations. Further, they are likely to find franchisees willing to build new units in any location with positive expected profits (taking into account the possibility of encroachment). ${ }^{4}$ The company-owned

\footnotetext{
${ }^{3}$ Intrabrand competition may also facilitate extraction of rents from the franchisees. See, e.g., Desiraju (2004)

${ }^{4}$ The franchisees are not likely to have a significant reservation wage outside the franchise relationship. Knott (2001), for example, found that print-shop franchisees who voluntarily severed ties
} 
Table 1 Hotel Counts of 10 Largest Chains in Texas, 1991-2000

\begin{tabular}{|c|c|c|c|c|c|c|c|c|}
\hline & \multicolumn{2}{|c|}{$\begin{array}{l}\text { Hotel count } \\
\text { (Jan. 1991) }\end{array}$} & \multicolumn{2}{|c|}{$\begin{array}{c}\text { Entries } \\
(1991-1999)\end{array}$} & \multicolumn{2}{|c|}{$\begin{array}{c}\text { Exits } \\
(1991-1999)\end{array}$} & \multicolumn{2}{|c|}{$\begin{array}{l}\text { Hotel count } \\
\text { (Jan. 2000) }\end{array}$} \\
\hline & Franch. & Co-own. & Franch. & Co-own. & Franch. & Co-own. & Franch. & Co-own. \\
\hline \multicolumn{9}{|c|}{ Franchised Brands } \\
\hline Holiday Inn & 77 & 13 & 89 & 5 & 34 & 4 & 132 & 14 \\
\hline Best Western & 65 & 0 & 105 & 0 & 26 & 0 & 144 & 0 \\
\hline Comfort Inn & 26 & 2 & 94 & 0 & 15 & 1 & 105 & 1 \\
\hline Econolodge & 27 & 0 & 26 & 0 & 20 & 0 & 33 & 0 \\
\hline Days Inn & 55 & 0 & 100 & 0 & 27 & 0 & 128 & 0 \\
\hline Ramada & 37 & 0 & 76 & 0 & 31 & 0 & 82 & 0 \\
\hline Super 8 & 14 & 0 & 73 & 0 & 4 & 0 & 83 & 0 \\
\hline Hampton Inn & 16 & 2 & 41 & 3 & 2 & 0 & 55 & 5 \\
\hline Total & 317 & 17 & 604 & 8 & 159 & 5 & 762 & 20 \\
\hline \multicolumn{9}{|c|}{ Co-owned Brands } \\
\hline La Quinta & 3 & 79 & 0 & 22 & 0 & 1 & 3 & 100 \\
\hline Motel 6 & 1 & 73 & 12 & 20 & 2 & 8 & 11 & 85 \\
\hline Total & 4 & 152 & 12 & 42 & 2 & 9 & 14 & 185 \\
\hline
\end{tabular}

Note. Holiday Inn includes the Holiday Inn Express brand extension; Ramada includes Ramada Limited; and Comfort Inn includes Comfort Suites.

firms, compensated directly by their units' profit, should choose only locations where profits at the new unit outweigh any resulting losses at neighboring locations. Because this constraint is more stringent than that faced by the franchisors, there exists a set of locations where company-owned firms will refrain from opening units but where franchisors will not hesitate to open units. Therefore, we should observe greater revenue losses at incumbent units due to encroachment within the franchised chains than within the company-owned chains.

One final argument is considered that does not imply negative encroachment effects. Additional units in a market may lead to a brand awareness externality as well as economies of scale in marketing (Blair and Lafontaine 2002). Those authors highlight the fact that franchisors have often been accused by franchisees of opening too few units within a market, as well as too many. If the value of the incumbent's brand is enhanced due to same-brand entry in its vicinity, we should observe revenue gains at the incumbent units of the franchised as well as company-owned chains. More generally, by agglomerating, groups of retail or service businesses could attract more customers than the sum of those the group members would attract in isolation, as long as personal inspection is required to assess product heterogeneity (Fischer and Harrington 1996). Chung and Kalnins (2001) argue that hotels are likely to meet this criterion, a point also made by hotel executives (Khanna and Ganot 1995, p. 8).

with their franchisor but maintained operations consistently suffered lower revenues and profits after the severance.
If agglomeration effects outweigh competitive effects across brands, we should observe revenue gains at incumbent units arising from proximate entry by hotels of the same brand as well as those of other brands.

\section{Data}

\subsection{Source of Data}

I analyzed publicly available data provided by the Texas Comptroller of Public Accounts. The population consists of all lodging establishments that operated in Texas at any time between January 1990 and December 1999. In addition to quarterly taxable revenues for each hotel, the data include the owner name and address, business name (including any brand affiliation) and address, and room count. The taxable revenues include only those earned from room rental. The quarterly revenues divided by the room count, a standard performance measure used in the industry, is the dependent variable in all regressions. The data set also includes entry and exit dates for each brand/owner/location combination. Every time an ownership transfer of a hotel takes place, a new "entry date" is included for the hotel for the new owner. Similarly, if an establishment changes brand, separate dates are usually included. The data set does not include any information about pricing of rooms or levels of occupancy.

\subsection{Empirical Regularities}

Table 1 shows the distribution of franchised and company-owned hotels in Texas in the 1990s and confirms that the ten largest brands are mostly limited 
to only one governance form. Among the eight hotel brands that are primarily franchised, only 20 units (or $2.5 \%$ ) out of 782 are company-owned. La Quinta and Motel 6 franchised only 14 (or 7\%) out of 199 total properties operating in 1999. A majority of the 12 franchised Motel 6 units were added in 1998 or 1999 , when the company began franchising on a regular basis.

Table 1 also shows that La Quinta and Motel 6 were among the largest brands in 1991, with 82 and 74 units, respectively. Only Holiday Inn (including the Holiday Inn Express brand extension) was larger, with 90 units. The initial large size of La Quinta and Motel 6 suggests that, if not taking company ownership into account, we should be most likely to observe encroachment within these chains. However, La Quinta added 22 units and Motel 6 added 32 units, while 7 of the 8 franchised chains added more than 32 units. The large initial unit count of the companyowned brands is not likely the cause of their slow growth, I argue, because Holiday Inn and Holiday Inn Express added 94 units despite its initial large size. Unlike the franchisors, the company-owned brands may have been adding locations more slowly because they were refraining from opening properties at some locations that lowered their overall profits.

Though not listed separately in Table 1, brand conversions are a common if not dominant phenomenon in the lodging industry. Among the 612 entries of the eight franchised brands, 81 (or 13\%) were conversions from any of the 62 brands operating in Texas in the 1990s, while the rest were newly branded foundings. Among the 164 exits that took place among the franchised chains, 76 (or 46\%) were conversions to any other brand and the rest were closings, i.e., hotels that ceased to be branded operations. Of these 76 hotels, 48 were upscale before the conversion, but only 33 were upscale after. Khanna and Ganot (1995, p. 3) noted that hotels often convert to brands of lower tier to avoid major renovations demanded by the upscale franchisors. An additional 127 hotels converted from nonbranded properties to the ten brands analyzed in this study. In the results presented below, these were not treated as conversions but rather as new foundings. Twenty-eight properties converted from one of the ten brands to a nonbranded property. These were treated as closings.

Finally, I note that the company-owned chains closed down fewer hotels than the franchised chains, suggesting greater care taken in the initial location choice. Only nine hotels of the two company-owned brands closed in the 1990s $(4.5 \%$ of the 199 that were open in 1999), while 94 hotels of the franchised chains $(12 \%$ of the 782 that were open in 1999) closed.

\subsection{Data Sets Used for Analysis}

The data sets used in the final analyses consist of 16,205 quarterly observations for 1,128 brand / owner / location combinations affiliated with the 8 franchised hotel brands, and 5,942 quarterly observations for 187 combinations of the large company-owned brands. These two data sets are analyzed separately. The raw data for all 10 brands included 28,160 quarterly observations. Of these, 4 separate groups of data, a total of 6013 observations, were removed.

First, while 1993 quarterly observations exist from the year 1990, these data could not be included in the analyses because lagged revenues were needed for a spatial lag variable. Second, 600 observations were removed for quarters within which a closing, ownership change, or brand conversion took place, because such changes yielded artificially low revenues. Third, some hotels reported zero revenues for some calendar quarters, possibly from remodeling efforts. To avoid spurious revenue heterogeneity arising from these temporary closings, I removed all 2711 observations associated with the 186 brand/owner/location combinations that reported zero revenues for one or more quarters. Fourth, because this study compares encroachment effects between franchised and company-owned chains, I removed 517 observations associated with company-owned brand/owner/location combinations within the franchised chains, and 192 observations associated with franchised combinations of the two company-owned brands.

As discussed in the robustness tests section, significance levels of the results presented below did not change when the additional observations associated with each of the four groups of data were included. I note that all hotels affiliated with each chain, regardless of whether company-owned or franchised and even when not included as observations of analysis, are included in the entry and exit count independent variables described below.

\section{Research Design}

\subsection{Method}

I estimated two-factor fixed-effects regression models with a dependent variable of taxable revenues per room per calendar quarter. A fixed effect is included for every distinct brand/owner/location combination. In other words, an additional intercept is assigned to the same hotel every time an ownership transfer or brand conversion took place. By controlling for the influence of brand and owner idiosyncrasies in this fashion, I can capture encroachment effects with a lower likelihood of confounding factors that could generate revenue heterogeneity.

A fixed effect is also included for every brand/year combination. Yearly intercepts capture exogenous 
economic shocks as well as overall growth and inflation. I include separate yearly effects for each brand to eliminate the possibility that effects attributed to encroachment variables actually result from periods of discontinuous growth for a brand. This is a concern because the greater the growth of a brand, the more likely that new units affiliated with that brand will encroach on incumbent units. Simpler specifications with only a year effect in place of the year/brand effect, or with only a single time trend variable, yielded results of marginally greater economic magnitude and with identical significance levels to those presented below.

While fixed effects are used exclusively throughout the analysis, I also considered the use of random effects models. However, for every specification I estimated, the Hausman test resoundingly rejected (at $p<0.001$ ) the null hypothesis that the coefficients of the fixed and random effects models are identical, indicating that the random effects approach is inappropriate.

\subsection{Independent Variables: Definitions of the Encroachment Area}

I defined hotels opened between 1991 and 1999 as encroaching on an incumbent hotel of the same brand if the new hotel appears within the incumbent's "encroachment area." With the intent of defining an area within which customers are likely to view two same-brand hotels as substitutes, I defined the encroachment area as the distance to a specified ordinally proximate branded chain hotel (e.g., the 10th closest) from the incumbent. To measure these distances, I obtained latitude and longitude coordinates based on street address for all branded hotels in Texas. Using these coordinates, I calculated the geographic distance from the 10th, 15th, and 20th closest hotel operating in 1995 to the incumbent's location. I defined all encroachment areas based on hotels existing in 1995 to keep the area constant throughout each hotel's life span.

The main benefit of the "closest hotel" approach is that it allows the encroachment area to vary in size, to take into account greatly differing population and commercial densities. In rural areas, the distance to the 10th-closest hotel may be 30 or 40 miles, while in urban areas this distance may be as little as two miles. These both likely represent valid areas within which hotels of the same brand are viewed as substitutes by consumers. In rural areas, consumers are likely to view geographically distant hotels as substitutes if they are at major exits of the same highway, for example (see Patel and Corgel 1995, Footnote 5).

Completely exogenous administrative boundaries (e.g., counties, metropolitan statistical areas (MSAs), zip codes) or fixed mileage distance radii are not usable as encroachment areas. Counties and MSAs vary far too greatly in terms of size. Harris County (home of Houston) had 114 hotels of the ten brands of this study in 1999, while Deaf Smith County had only one, a Best Western. The Houston MSA had 136 hotels of the ten brands, while the San Angelo MSA had only nine. Zip codes have been used to examine the agglomeration of the hotels of multiple brands (Chung and Kalnins 2001), but zips are too small to capture the effects of encroachment. In the Texas data, only 18 hotels were opened in zip codes with an incumbent of the same brand. Finally, fixed mileage radii present problems because of hotel density variation across different locations, as mentioned above. However, regressions were estimated with the 10th, 15th, and 20th closest hotel distances further circumscribed by a 25-mile cutoff. As discussed in the robustness test section, these results were even stronger than those presented.

\subsection{Independent Variables: Entries and Exits within the Encroachment Area}

All same-brand hotels that entered an incumbent's encroachment area during its life span are added to the "entries of same brand" variable, from the time of entry onward. In some regressions, the entry variable is split into two components, "conversions to same brand" and "same-brand foundings." Only four units converted from other brands to the two companyowned brands, so conversions and foundings are not analyzed separately for these two brands.

All hotels of the same brand that exited within an incumbent's encroachment area are included in the "exits of same brand" variable from their date of exit onward. Like the corresponding entry variable, the "exits of same brand" variable is split into two components, "conversions from same brand" and "closings of same brand." For La Quinta and Motel 6, only two units were converted to other brands, while only nine closed down. For this reason, the revenue effects of exits could not be analyzed for the two companyowned brands.

In the analysis of the franchised brands, a new same-brand hotel in the vicinity of an incumbent unit is added to the "entries of same brand" variable even if both hotels are owned by the same franchisee. While multiunit franchisees that own several proximate units are common in fast-food franchising (see, e.g., Kalnins and Lafontaine 2004), there are too few cases here of the same franchisee owning a new hotel close to an existing same-brand unit to analyze these cases separately. Among the 1,128 franchised brand/owner/location combinations included in the analysis, only for 11 did the same owner open another hotel of the same brand closer than the 10th branded hotel, and this number increased only to 14 for the 
closest 20th. Results did not change when these hotels were removed from the entry and exit counts.

\subsection{Definitions of Other Independent Variables}

Counts of new hotels of other brands within the encroachment area are also included so that the samebrand and other-brand entry effects can be compared. I count separately the upscale and economy hotels to distinguish between competition from same-tier and other-tier hotels. This approach also allows an examination of possible agglomeration benefits that may outweigh competitive effects in some cases, particularly between hotels of different tiers (Baum and Haveman 1997, Kalnins and Chung 2004). If a given hotel is "upscale," then the counts of upscale hotels of other brands are included in the "new sametier/other-brand hotels" variable; if the given hotel is "economy," then this variable consists of other economy brands. The "new other-tier hotels" variable consists of the count of upscale entries for an economy hotel and vice versa. The upscale brands were split from the economy brands based on a brand's average AAA rating in Texas of 2.5 stars in the 1998 guidebook. Holiday Inn, Comfort Inn, La Quinta, and Hampton Inn are considered upscale; Comfort Inn was the lowest ranked upscale chain, with 2.74 stars. Best Western, Econolodge, Ramada, Days Inn, Super 8, and Motel 6 are economy brands; Ramada was the highest economy chain, with an average of 2.44 stars.

While the brand/owner/location combination fixed effects eliminate any influence of time-invariant regional heterogeneity and the brand/year intercepts similarly eliminate temporal effects, they do not eliminate heterogeneity that is both time- and regionspecific. A region might experience sudden economic growth, for example, causing both higher revenues for existing units and entry of new units. If not controlled for, temporal/regional heterogeneity can bias results against the finding of encroachment effects. The extensive spatial econometrics literature (e.g., Anselin 1988, Kalnins 2003) uses "spatial lag" variables as a control. I constructed the spatial lag using the average of revenues per room at other existing branded hotels within the encroachment area, temporally lagged by one year to avoid simultaneity biases.

I include the number of retail establishments in the zip code where the hotel is located, as well as the net change of retail establishments from the year previous to that of the given observation. I include dummies for spring, summer, and autumn because many hotels in Texas exhibit substantial seasonal variation in revenues. Coefficients of the seasonal dummies are not included in the tables to conserve space, but they are present in all regressions.

Table 2 presents two sets of descriptive statistics, one for the eight franchised brands and one for the two company-owned brands. In addition to the standard statistics of mean, standard deviation, minimum and maximum, the table presents a fifth column marked "NonZ." This column shows the number of brand/owner/location combinations for which at least one (i.e., a nonzero count) same-brand entry (or exit) takes place in the incumbent's encroachment areas while that incumbent is in operation. For example, the first value in the NonZ column for the franchised brands states that for 220 incumbent brand/ owner/location combinations, at least one entry of the same brand took place within the "10th closest" definition of the incumbent's encroachment area. The next two values in the column indicate that at least one brand conversion took place within the "10th closest" encroachment area for 30 incumbents, and at least one founding took place within this area for 200 incumbents. Ten hotels were affected by both an encroaching conversion and a founding.

Beyond the information given in the descriptive statistics, I note that the company-owned chains located their hotels slightly closer to their existing hotels than did the franchised chains. When a samebrand entry occurred closer to an incumbent than the 10th closest branded hotel, on average the entrant was 5.91 hotels away for the franchised chains, and 5.64 hotels away for the company owned chains. Entrants within the 15th closest area were, on average, 8.92 hotels away for the franchised chains and 8.30 hotels away for the company-owned chains. For the 20th closest, these numbers are 11.41 and 10.71, respectively.

In addition, entries and exits rarely take place in the same area, so they do not represent the building of replacement facilities. Using the "10th closest" encroachment area definition, of the 220 franchised incumbent hotels that experienced same-brand entry, only 37 also experienced a same-brand exit. Using the "15th closest" definition, of the 337 franchised incumbents that experienced encroachment, only 57 also experienced a same-brand exit.

\section{Results}

\subsection{Core Results}

Table 3 presents results from two-factor fixed-effects regressions. The first six columns show results for the eight franchised chains, and the last three present results for the company-owned brands. For the franchised chains, the first two columns use the "10th closest" definition of the encroachment area, the third and fourth use the 15th closest, and the fifth and sixth use the 20th closest. Two regressions are presented using each distance cutoff. The first uses the "entries of same brand" and "exits of same brand" variables. The second splits the "entry" variable into 
Descriptive Statistics for Franchised and Company-Owned Brands

\begin{tabular}{|c|c|c|c|c|c|c|c|c|c|c|}
\hline & \multicolumn{5}{|c|}{ Franchised chains } & \multicolumn{5}{|c|}{ Company-owned brands } \\
\hline & Mean & SDev & Min & $\operatorname{Max}$ & NonZ & Mean & SDev & Min & $\operatorname{Max}$ & NonZ \\
\hline Revenues per room (\$000s) & 2.29 & 1.14 & 0.00 & 13.31 & & 2.57 & 0.99 & 0.28 & 6.80 & \\
\hline \multicolumn{11}{|l|}{ Encroach. area 10th closest hotel } \\
\hline Entries of same brand & 0.20 & 0.51 & 0 & 5 & 220 & 0.08 & 0.31 & 0 & 2 & 27 \\
\hline Conversions to same brand & 0.02 & 0.15 & 0 & 1 & 30 & 0.03 & 0.21 & 0 & 2 & 8 \\
\hline Same-brand foundings & 0.18 & 0.47 & 0 & 5 & 200 & 0.05 & 0.22 & 0 & 2 & 20 \\
\hline New same-tier/other-brand hotels & 1.35 & 1.78 & 0 & 18 & & 2.28 & 2.50 & 0 & 18 & \\
\hline New other-tier hotels & 1.41 & 1.83 & 0 & 18 & & 2.14 & 2.38 & 0 & 16 & \\
\hline Exits of same brand & 0.05 & 0.25 & 0 & 2 & 55 & 0.03 & 0.17 & 0 & 1 & 6 \\
\hline Conversions from same brand & 0.03 & 0.16 & 0 & 1 & 27 & 0.01 & 0.11 & 0 & 1 & 2 \\
\hline Same-brand closings & 0.03 & 0.17 & 0 & 2 & 31 & 0.02 & 0.14 & 0 & 1 & 4 \\
\hline Same-tier/other-brand closings & 0.15 & 0.39 & 0 & 3 & & 0.25 & 0.52 & 0 & 3 & \\
\hline Other-tier closings & 0.12 & 0.37 & 0 & 3 & & 0.32 & 0.58 & 0 & 4 & \\
\hline Spatially lagged revenues (\$000s) & 2.67 & 0.99 & 0.56 & 10.15 & & 2.70 & 0.95 & 0.82 & 9.48 & \\
\hline \multicolumn{11}{|l|}{ Encroach. area 15th closest hotel } \\
\hline Entries of same brand & 0.35 & 0.66 & 0 & 6 & 337 & 0.13 & 0.39 & 0 & 2 & 44 \\
\hline Conversions to same brand & 0.04 & 0.19 & 0 & 1 & 48 & 0.05 & 0.24 & 0 & 2 & 10 \\
\hline Same-brand foundings & 0.31 & 0.62 & 0 & 6 & 312 & 0.09 & 0.31 & 0 & 2 & 35 \\
\hline New same-tier/other-brand hotels & 2.06 & 2.47 & 0 & 22 & & 3.44 & 3.39 & 0 & 21 & \\
\hline New other-tier hotels & 2.13 & 2.48 & 0 & 20 & & 3.16 & 3.28 & 0 & 21 & \\
\hline Exits of same brand & 0.08 & 0.30 & 0 & 2 & 96 & 0.03 & 0.17 & 0 & 1 & 6 \\
\hline Conversions from same brand & 0.04 & 0.20 & 0 & 2 & 43 & 0.01 & 0.11 & 0 & 1 & 2 \\
\hline Same-brand closings & 0.04 & 0.21 & 0 & 2 & 56 & 0.02 & 0.14 & 0 & 1 & 4 \\
\hline Same-tier/other-brand closings & 0.23 & 0.50 & 0 & 4 & & 0.43 & 0.70 & 0 & 4 & \\
\hline Other-tier closings & 0.21 & 0.48 & 0 & 4 & & 0.51 & 0.74 & 0 & 5 & \\
\hline Spatially lagged revenues (\$000s) & 2.71 & 0.96 & 0.74 & 8.38 & & 2.75 & 0.97 & 1.00 & 8.18 & \\
\hline \multicolumn{11}{|l|}{ Encroach. area 20th closest hotel } \\
\hline Entries of same brand & 0.49 & 0.84 & 0 & 7 & 418 & 0.18 & 0.44 & 0 & 3 & 55 \\
\hline Conversions to same brand & 0.05 & 0.23 & 0 & 2 & 69 & 0.05 & 0.25 & 0 & 2 & 11 \\
\hline Same-brand foundings & 0.44 & 0.79 & 0 & 7 & 391 & 0.13 & 0.36 & 0 & 2 & 47 \\
\hline New same-tier/other-brand hotels & 2.74 & 3.06 & 0 & 26 & & 4.62 & 4.32 & 0 & 25 & \\
\hline New other-tier hotels & 2.85 & 3.15 & 0 & 24 & & 4.28 & 4.16 & 0 & 24 & \\
\hline Exits of same brand & 0.11 & 0.34 & 0 & 2 & 127 & 0.04 & 0.19 & 0 & 1 & 8 \\
\hline Conversions from same brand & 0.05 & 0.23 & 0 & 2 & 60 & 0.01 & 0.11 & 0 & 1 & 2 \\
\hline Same-brand closings & 0.06 & 0.24 & 0 & 2 & 72 & 0.03 & 0.16 & 0 & 1 & 6 \\
\hline Same-tier/other-brand closings & 0.29 & 0.59 & 0 & 6 & & 0.61 & 0.86 & 0 & 4 & \\
\hline Other-tier closings & 0.28 & 0.59 & 0 & 4 & & 0.70 & 0.87 & 0 & 5 & \\
\hline Spatially lagged revenues (\$000s) & 2.74 & 0.92 & 0.89 & 7.64 & & 2.77 & 0.91 & 1.07 & 6.82 & \\
\hline Retail count in zip (00s) & 0.29 & 0.18 & 0.00 & 1.02 & & 0.33 & 0.20 & 0.00 & 1.02 & \\
\hline Net retail additions in zip & 0.01 & 0.02 & -0.07 & 0.32 & & 0.02 & 0.03 & -0.07 & 0.15 & \\
\hline
\end{tabular}

the number of conversions and the number of samebrand foundings. The "exits" variable is split into the number of conversions to other brands and the number of same-brand closings. Only three columns, with the "entries of same brand" variable, are presented for the company-owned brands. Splits of this variable are not presented because only four brand conversions to these two chains took place in the 1990s. In addition, the "exits of same brand" variable could not be included because the company-owned brands experienced only 11 exits.

The "entries of same brand" variable is negative and significant in columns 1,3 , and 5, indicating that within the eight franchised chains, revenues of incumbent hotels significantly decrease when a proximate same-brand unit is added. A new same-brand unit within the closest 10 hotels is associated with a loss of $\$ 66$ per room each quarter, while a same-brand hotel among the closest 20 is associated with a loss of $\$ 51$. Because the mean hotel size among the 10 chains studied here is 110 rooms, the revenue losses associated with same-brand entry translate into a loss of between $\$ 7,360$ and $\$ 5,610$ per quarter, or between $2.7 \%$ and $2 \%$ of the mean revenues.

The results for hotels of the company-owned brands are presented in columns 7-9 of Table 3. The difference between the proximate same-brand entry effects for the franchised brands and the companyowned brands is striking. A new entrant of the same brand is associated with a per-room quarterly gain of 
Table 3

Two-Factor Fixed Effects Regressions on Quarterly Revenues per Room

\begin{tabular}{|c|c|c|c|c|c|c|c|c|c|}
\hline \multirow[b]{3}{*}{ Encroachment area defined as: } & \multicolumn{6}{|c|}{$\begin{array}{l}\text { Franchised hotel chains: } 16,205 \text { quarterly observations for } \\
\qquad 1,128 \text { brand/owner/location combinations }\end{array}$} & \multicolumn{3}{|c|}{$\begin{array}{l}\text { Company-owned hotel chains: } \\
5942 \text { Obs. for } 187 \text { B/O/Locs. }\end{array}$} \\
\hline & \multicolumn{2}{|c|}{ Closest 10} & \multicolumn{2}{|c|}{ Closest 15} & \multicolumn{2}{|c|}{ Closest 20} & \multirow{2}{*}{$\begin{array}{c}\text { Closest } 10 \\
(7)\end{array}$} & \multirow{2}{*}{$\begin{array}{c}\text { Closest } 15 \\
(8)\end{array}$} & \multirow{2}{*}{$\begin{array}{c}\text { Closest } 20 \\
(9)\end{array}$} \\
\hline & (1) & $(2)$ & (3) & (4) & (5) & (6) & & & \\
\hline Entries of same brand & $\begin{array}{c}-66.81^{* *}, \$ \\
(15.55)\end{array}$ & & $\begin{array}{l}-64.3^{* *}, \$ \$ \\
(12.37)\end{array}$ & & $\begin{array}{l}-51.0^{* *}, \$ \$ \\
(10.30)\end{array}$ & & $\begin{array}{l}119.32^{* *} \\
(30.25)\end{array}$ & $\begin{array}{l}96.08^{* *} \\
(21.94)\end{array}$ & $\begin{array}{l}74.49 * * \\
(19.10)\end{array}$ \\
\hline Conversions to same brand & & $\begin{array}{l}-71.56 \\
(47.04)\end{array}$ & & $\begin{array}{r}-80.53^{*} \\
(39.40)\end{array}$ & & $\begin{array}{c}-85.16^{* *} \\
(32.27)\end{array}$ & & & \\
\hline Same-brand foundings & & $\begin{array}{c}-66.03^{* *} \\
(16.55)\end{array}$ & & $\begin{array}{c}-62.12^{* *} \\
(13.02)\end{array}$ & & $\begin{array}{c}-47.46^{* *} \\
(10.88)\end{array}$ & & & \\
\hline New same-tier/other-brand hotels & $\begin{array}{c}-36.27^{* *} \\
(4.96)\end{array}$ & $\begin{array}{c}-36.33^{* *} \\
(4.96)\end{array}$ & $\begin{array}{c}-30.41^{* *} \\
(3.85)\end{array}$ & $\begin{array}{c}-30.73^{* *} \\
(3.86)\end{array}$ & $\begin{array}{c}-25.65^{* *} \\
(3.34)\end{array}$ & $\begin{array}{c}-26.09 * * \\
(3.35)\end{array}$ & $\begin{array}{c}-46.20^{* *} \\
(4.50)\end{array}$ & $\begin{array}{c}-34.57^{* *} \\
(3.59)\end{array}$ & $\begin{array}{c}-34.76 * * \\
(2.91)\end{array}$ \\
\hline New other-tier hotels & $\begin{array}{c}-17.09^{* *} \\
(4.98)\end{array}$ & $\begin{array}{c}-17.08^{* *} \\
(4.98)\end{array}$ & $\begin{array}{c}-5.02 \\
(4.11)\end{array}$ & $\begin{array}{l}-5.05 \\
(4.11)\end{array}$ & $\begin{array}{c}-6.13^{+} \\
(3.44)\end{array}$ & $\begin{array}{c}-6.14^{+} \\
(3.44)\end{array}$ & $\begin{array}{c}-15.71^{* *} \\
(4.62)\end{array}$ & $\begin{array}{c}-24.41^{* *} \\
(3.56)\end{array}$ & $\begin{array}{c}-24.24^{* *} \\
(2.97)\end{array}$ \\
\hline Exits of same brand & $\begin{array}{c}54.32 \\
(36.28)\end{array}$ & & $\begin{array}{l}128.5^{* *}, \$ \$ \\
(28.88)\end{array}$ & & $\begin{array}{l}102.1^{* *}, \$ \$ \\
(24.94)\end{array}$ & & & & \\
\hline Conversions from same brand & & $\begin{array}{c}66.62 \\
(58.93)\end{array}$ & & $\begin{array}{c}171.73^{* *} \\
(46.03)\end{array}$ & & $\begin{array}{l}164.85^{* *} \\
(38.06)\end{array}$ & & & \\
\hline Same-brand closings & & $\begin{array}{c}46.82 \\
(46.08)\end{array}$ & & $\begin{array}{l}101.18^{* *} \\
(36.46)\end{array}$ & & $\begin{array}{c}56.67^{+} \\
(32.14)\end{array}$ & & & \\
\hline Same-tier/other-brand closings & $\begin{array}{c}34.60 \\
(21.08)\end{array}$ & $\begin{array}{c}34.75^{+} \\
(21.09)\end{array}$ & $\begin{array}{c}30.22^{+} \\
(16.81)\end{array}$ & $\begin{array}{c}30.86^{+} \\
(16.81)\end{array}$ & $\begin{array}{c}25.51^{+} \\
(14.84)\end{array}$ & $\begin{array}{c}25.53^{+} \\
(14.84)\end{array}$ & $\begin{array}{c}119.27^{* *} \\
(18.09)\end{array}$ & $\begin{array}{c}84.88^{* *} \\
(14.34)\end{array}$ & $\begin{array}{c}77.83^{* *} \\
(12.44)\end{array}$ \\
\hline Other-tier closings & $\begin{array}{l}66.78^{* *} \\
(22.02)\end{array}$ & $\begin{array}{l}66.77^{* *} \\
(22.02)\end{array}$ & $\begin{array}{c}8.80 \\
(17.87)\end{array}$ & $\begin{array}{c}7.82 \\
(17.89)\end{array}$ & $\begin{array}{c}1.27 \\
(15.36)\end{array}$ & $\begin{array}{c}0.08 \\
(15.39)\end{array}$ & $\begin{array}{l}-8.57 \\
(18.61)\end{array}$ & $\begin{array}{c}20.54 \\
(14.51)\end{array}$ & $\begin{array}{c}36.60^{* * *} \\
(12.85)\end{array}$ \\
\hline Retail count in zip code & $\begin{array}{l}0.83^{* *} \\
(0.18)\end{array}$ & $\begin{array}{l}0.83^{* *} \\
(0.18)\end{array}$ & $\begin{array}{l}0.85^{* *} \\
(0.18)\end{array}$ & $\begin{array}{l}0.84^{* *} \\
(0.18)\end{array}$ & $\begin{array}{l}0.81^{* *} \\
(0.18)\end{array}$ & $\begin{array}{l}0.80^{* *} \\
(0.18)\end{array}$ & $\begin{array}{l}0.63^{* *} \\
(0.19)\end{array}$ & $\begin{array}{l}0.84^{* *} \\
(0.19)\end{array}$ & $\begin{array}{l}0.54^{* *} \\
(0.19)\end{array}$ \\
\hline Net retail additions in zip code & $\begin{array}{l}0.85^{* *} \\
(0.31)\end{array}$ & $\begin{array}{l}0.85^{* *} \\
(0.31)\end{array}$ & $\begin{array}{c}0.70^{*} \\
(0.31)\end{array}$ & $\begin{array}{c}0.71^{*} \\
(0.31)\end{array}$ & $\begin{array}{c}0.66^{*} \\
(0.31)\end{array}$ & $\begin{array}{c}0.67^{*} \\
(0.31)\end{array}$ & $\begin{array}{c}0.81^{* *} \\
(0.31)\end{array}$ & $\begin{array}{c}0.60^{+} \\
(0.31)\end{array}$ & $\begin{array}{c}0.53^{+} \\
(0.30)\end{array}$ \\
\hline Spatially lagged revenues & $\begin{array}{l}0.34^{* *} \\
(0.01)\end{array}$ & $\begin{array}{l}0.34^{* *} \\
(0.01)\end{array}$ & $\begin{array}{l}0.37^{* *} \\
(0.01)\end{array}$ & $\begin{array}{l}0.37^{* *} \\
(0.01)\end{array}$ & $\begin{array}{l}0.40^{* *} \\
(0.01)\end{array}$ & $\begin{array}{l}0.40^{* *} \\
(0.01)\end{array}$ & $\begin{array}{l}0.34^{* *} \\
(0.01)\end{array}$ & $\begin{array}{l}0.34^{* *} \\
(0.01)\end{array}$ & $\begin{array}{l}0.40^{* *} \\
(0.01)\end{array}$ \\
\hline R-squared & 0.26 & 0.26 & 0.26 & 0.26 & 0.26 & 0.26 & 0.46 & 0.47 & 0.49 \\
\hline
\end{tabular}

Note. There are separate fixed effects for each brand/owner/location combination and each brand/calendar quarter combination.

$+p<0.10$.

$* p<0.05$.

${ }^{* *} p<0.01$ in two-tailed tests.

$\$ \$$ Indicates that "Entries of same brand" is significantly greater in magnitude than "New same-tier/other brand hotels" (or "Exits of same brand" is greater than "Same-tier/other brand closings") at $p<0.05$ via an F-test; $\$$ same at $p<0.10$.

$\$ 119$ to $\$ 75$, depending on the size of the encroachment area.

When the "entries of same brand" variable is split into "conversions of same brand" and "same-brand foundings" for the franchised chains in columns 2, 4, and 6 , both of these variables are negative and significant. The sole exception is the conversions variable within the 10-hotel encroachment area, which is shy of statistical significance $(p=0.138)$. Conversions reduce existing hotels' revenue by $\$ 71$ to $\$ 86$, depending on the encroachment area, while foundings reduce revenues by $\$ 66$ to $\$ 47$. The reason for the larger effect of brand conversions is probably because they are larger hotels. I discuss this issue in the "robustness tests" section below.

In contrast to same-brand entry, same-tier/otherbrand entry within an incumbent's encroachment area consistently has significantly negative revenue effects, not only for the franchised chains but also for the company-owned brands. For the franchised chains, the losses to incumbents due to same-brand entries are significantly greater than the losses associated with new same-tier/other-brand hotels; an F-test on the difference between the two coefficients is statistically significant at $p<0.10$ for the "10th closest hotel" definition and at $p<0.05$ for the 15th closest and 20th closest definitions. New other-tier hotels within the encroachment area also cause significant losses: between $\$ 17$ and $\$ 6$, depending on the encroachment area.

Turning now to exits, the "exits of same brand" variable is positive and significant in columns 3 and 5, indicating that in the case of the eight franchised chains, revenues of incumbent hotels significantly increase when a hotel of the same brand is shut down or converted to another brand in their vicinity. The exit of a same-brand hotel within the closest 15 and 20 hotels is associated with a gain of $\$ 129$ and $\$ 102$, respectively, per room per quarter.

The "exits of same brand" variable is split into "conversions from same brand" and "same-brand 
closings" in columns 2, 4, and 6. Conversions to a different brand are associated with increases in existing hotels' revenue of $\$ 172$ for the 15th closest hotel definition of the encroachment area, and $\$ 165$ for the "20th closest" definition, while the closing down of a same-brand hotel increases revenues by $\$ 101$ and $\$ 57$ for these two encroachment area definitions. Sametier/other-brand exits are positive and marginally significant, but other-tier exits within an incumbent's encroachment area have negligible revenue effects for franchised incumbent hotels.

The retail count and growth variables in a hotel's zip code are consistently significant, indicating a revenue gain of between 54 and 83 cents per existing retail business, while the net change in retail establishments from the previous year is associated with an additional gain similar in magnitude. The spatial lags, i.e., the lagged revenues of other existing branded hotels within the encroachment area, are highly significant. The lagged revenues have coefficients of between 0.34 and 0.40 , indicating that over one-third of the revenue variance for each hotel across calendar quarters is the result of a temporal-spatial effect common to all branded hotels in the area. This strong result illustrates the importance of controlling for temporal-spatial effects beyond those captured by the brand/owner/location and brand/calendar quarter fixed effects.

\subsection{Subsample Results (Chain-by-Chain and Urban vs. Rural Areas)}

To eliminate the possibility that results within one or two of the chains are driving the overall economic and statistical significance, the specifications of the columns 1, 3, and 5 in Table 3 were estimated for each chain individually. Statistically significant and negative encroachment effects of same-brand entry were found for at least one of the three encroachment area definitions (10th, 15th, or 20th closest) for six of the eight franchised chains; four chains showed negative and significant effects for two of the three area definitions. Both the company-owned brands Motel 6 and La Quinta exhibited positive and significant effects associated with new hotels opening in the vicinity of their existing ones when analyzed separately, much like their joint effects presented in Table 3.

Interestingly, Super 8 was the only franchised brand that exhibited a positive and significant effect of new hotels opening in the vicinity of their existing ones. The significant effect was present when defining the encroachment area as the 10th or 15th closest hotel. This finding is interesting because, as discussed above in $\$ 2$, Super 8 was the only franchised chain that gave franchisees some territorial protection from encroachment throughout the 1990s. However, caution is required in interpreting the Super 8 results as an effect of the chain's protection clause, because two other variables (other-tier exits and net retail additions in zip code) exhibited significance in the opposite direction from the pooled regressions of Table 3.

I also split the sample into urban and rural subsamples. When estimated separately, the results of both subsamples were completely consistent with those of Table 3, other than one interesting exception: For the franchised chains, the "new other-tier hotels" is positive and significant in rural areas. Chung and Kalnins (2001) suggested that demand-based agglomeration effects should be particularly important for hotels in rural areas such as highway exits, because the cluster of hotels itself is likely to become the primary attraction in those areas. Both upscale and economy hotels benefited from the presence of other-tier entry, indicating that agglomeration benefits are mutualistic as suggested by Baum and Haveman (1997) and not asymmetric as suggested by Kalnins and Chung (2004).

\subsection{Encroachment by Other Brands of the Same Franchisor Corporation}

The analysis above treats all brands as identical in the definition of the "new same-tier" and "new othertier" variables. As mentioned above, some franchisors own multiple brands. Choice Hotels owns the Comfort and Econolodge brands, while Cendant owns Ramada, Days Inn, and Super 8. Franchisees of these brands have complained that encroachment can come not only from new hotels of their own brand but also from others owned by the same franchisor. Therefore, a "new same franchisor corporation" variable was created, and the hotels were not included in the counts for the "tiers" variables. While the revenue losses to existing hotels associated with the hotels of the same franchisor were slightly larger than those for others of different franchisors but of the same tier, the null hypothesis that these coefficients were the same could not be rejected.

\subsection{Additional Robustness Tests}

I conducted many additional robustness tests to be certain that the results presented above are not an artifact of any individual specification. These tests, discussed in detail below, support the notion that a negative encroachment effect is substantive and pervasive throughout the franchised hotel chains, while this is not the case for the company-owned brands.

First, as discussed above, I removed 517 observations associated with 32 company-owned brand/ owner/location combinations within the franchised chains, and 192 observations associated with 16 franchised combinations within the 2 company-owned brands. Regressions that included these observations along with the rest for their respective chains showed identical significance levels as those in Table 3. 
Second, also discussed above, some hotels have discontinuous revenue declines in certain quarters, which possibly stem from major remodeling efforts. For this reason, the results in Table 3 excluded all observations for brand/owner/location combinations that listed zero revenues at some point during their operation. When the zero-revenue brand/owner/ location combinations were included, the results were as statistically significant as those in Table 3. To further ensure that revenue outliers were not driving the results, I estimated regressions after removing the 5\% of brand/owner/location combinations that had the lowest revenues at some point during their operations (in addition to the zero-revenue combinations), and the $5 \%$ with the highest revenues. The results of these regressions are very similar to those of Table 3, but the coefficients associated with the "entries of samebrand" variable are reduced by approximately $25 \%$.

Third, to be assured that the three ordinals, the 10th, 15th, and 20th closest branded hotel, were not generating idiosyncratic results, I estimated 33 regressions using every ordinal from the 4 th to the 36th closest hotel as a radius for the encroachment area. For the franchised chains, encroachment effects are substantial (losses of more than $\$ 30$ per room per quarter) using radii of anywhere between the 6th and 24th closest hotel. All radii between the 8th and 22nd closest hotels were significant at $p<0.05$. The 12 th closest hotel radius maximizes the $\mathrm{R}$-squared. The gains per room for the company-owned hotels are statistically significant (and over \$30) over a broader range, up to the 35th closest hotel.

Fourth, a fixed-distance 25-mile radius was added to the "closest hotel" distances to further circumscribe the encroachment area. In other words, only hotels within the closest 10 th, 15 th, or 20 th hotels, and within 25 miles, were included in the encroachment area. Results using these definitions were even stronger, both in significance levels and economic magnitude, than those shown in Table 3. In particular, the "samebrand closings" variable using all three encroachment area definitions and the "conversions to same brand" variable for the "10th closest" encroachment area definition became highly significant.

Fifth, the results in Table 3 show that the effects of conversion entries and exits on the revenues of samebrand incumbents are greater in magnitude than the effects of openings and closings. These differences probably occur because conversions are larger (133 rooms) than new entrants (110 rooms). Regressions that defined the entry and exit variables in terms of number of rooms showed that, per room, conversion entries and exits have a slightly lower revenue effect on incumbent hotels than do openings and closings.

\subsection{Limitations}

The results presented in this paper provide the first systematic evidence regarding the economic importance of encroachment, but the results here are limited to one U.S. state and one industry. It is hoped that other researchers will find the data to analyze encroachment effects in other industries and geographic regions; additional work is clearly necessary to confirm or deny that encroachment is pervasive throughout the domain of franchising. Nevertheless, attributes of Texas as well as the hotel industry suggest that the findings here could indeed be generalizable. Texas is a large state with a wide variety of location types (e.g., urban, rural, major highways, and coastal resorts) that appear representative of those existing throughout the United States. While the hotel industry has some idiosyncrasies (lack of dual distribution within chains, properties that switch brands), the main structural features that lead to encroachment (market saturation, royalties based on sales rather than profits) are also present not only in lodging but also in other major franchised industries such as fast food.

\section{Discussion and Conclusions}

\subsection{Discussion}

Cumulatively, the results presented in this paper provide the first systematic evidence of encroachment. The main finding supporting encroachment is that within franchised chains, new units significantly cannibalize the revenues of proximate same-brand units. The results for the company-owned chains provide a stark contrast. While the units of the franchised and company-owned chains lose an almost identical amount of revenue following the entry of sametier/other-brand units in their vicinity, the addition of a new unit by a company-owned brand is associated with a revenue increase at the chain's incumbent units. Even among organizations such as the economy motel chains that appear indistinguishable in terms of physical assets, market niche, and transaction type, governance form clearly matters.

In addition, this paper presents evidence that an incumbent and an entrant must be affiliated with the same brand for noteworthy encroachment effects to occur. While same-tier/other-brand entry has a consistently negative and significant effect, incumbents lose significantly more revenues from samebrand entry than from same-tier/other-brand entry. This result implies that encroachment is not merely a competitive effect that results from a greater supply of same-tier hotels in a market. Supporting this point further is the finding that conversions by units of different brands to an incumbent's brand also have a large negative effect on the incumbent's revenues 
without increasing the market's supply at all. Thus, if there is any brand externality, it is clearly outweighed by the negative effects of encroachment.

The paper also presented economically and statistically significant results regarding same-brand exits. When units exit in the vicinity of same-brand incumbents, the incumbents enjoy substantial revenue increases. These beneficial effects of same-brand exits complement the detrimental effects of same-brand entry to support the idea that changes in same-brand market presence have the most substantial impact on an incumbent's bottom line.

As the analyses are not structural, the results should be interpreted as causal only with strong theoretical justification. Two such justifications were discussed in this paper for the revenue-reducing effect of same-brand entry within franchised chains. First, franchisors may be divisionalizing strategically in order to credibly commit to more market share. Like the divisions in the model of Baye et al. (1996), franchisees may actively compete against each other, resulting in lower profits for each franchisee but greater market share for their brand overall. Second, the franchisors' royalty structure gives them incentives to approve more new units than would the company-owned brands (Kaufmann and Rangan 1990). Existing franchised units will be more likely to experience encroachment than will be companyowned units as a result of either of these logics.

The positive relationship between incumbent revenues and same-brand entry within the companyowned chains, on the other hand, is more likely a correlation generated by unobservable market-level demand heterogeneity than a causal result. Increasing demand in a market will raise incumbents' revenues and attract entrants. While I included a spatially lagged dependent variable to control for regional/temporal heterogeneity, remaining unobservables probably explain at least some portion of the company-owned incumbents' revenue rise that follows same-brand entry. A possible causal explanation for this result is that of a brand awareness externality (e.g., Blair and Lafontaine 2002). Given the large number of units of the two company-owned brands already in existence in 1990, however, it is unlikely that these brands benefited from additional customer awareness when new units were added. The brand awareness externality is also not a likely explanation because the incumbent units of large franchised brands such as Holiday Inn and Best Western, similar in initial size to La Quinta and Motel 6 at the beginning of the study period, appeared to enjoy no such externality.

Regardless of whether it is a correlation or a causal result, the finding for company-owned brands serves as an important contrast to the negative revenue effects found for the franchised brands. The companyowned firms are likely restricting their additional units to those locations where the profits will outweigh losses at their nearby units. Markets with growing demand are likely to fulfill this condition. The franchisors appear to be acting consistently with incentives to approve units anywhere where franchisees are willing to build them.

\subsection{Implications for Research on Governance Form and Exclusive Territories}

The results of this paper inform theory regarding the effect of governance form on strategic choices such as market entry and on likelihood of channel conflict. The findings here suggest pros and cons of each of the two governance forms for the upstream franchisor. The franchisors in this study were able to add units at a faster rate than were the companyowned firms, suggesting that the strategic toughness enabled by franchising (Baye et al. 1996) and the incentive misalignment due to the royalty structure (Kaufmann and Rangan 1990) do allow franchisors to gain higher market share relative to company-owned firms. However, the results also showed that franchising generates the channel conflict of encroachment. Not only is the channel conflict costly for franchisors in terms of lobbying against anti-encroachment legislation and defending their contracts in courts, but the underlying misalignment of goals might also lead to greater opportunism (Anderson 1988). Franchisees commonly exhibit opportunism by "freeriding" on the brand's reputation by undersupplying quality (Brickley 1999); disgruntled franchisees suffering encroachment may be more likely to engage in such behavior. The goal misalignments between franchisees and franchisors, and among franchisees, may also inhibit cooperation (e.g., Jap 1999). For example, Darr et al. (1995) found that within a franchised chain, knowledge transferred effectively from unit to unit only if the same franchisee owned both units; no direct knowledge transfer occurred between proximate same-brand units of different franchisees. While not suggested by those authors, encroachmentinduced frictions between franchisees likely play a substantial role in this lack of cooperation.

This paper also contributes to our understanding of upstream firms' use of exclusive territories. The paper discussed two incentives for franchisors to eschew exclusivity—strategic toughness and greater royalties. Interestingly, other theoretical models suggest that assigning and enforcing exclusive territories is beneficial for upstream firms such as franchisors (e.g., Dutta et al. 1994). Similar models emphasize the combination of vertical separation and exclusive territories as a means of keeping downstream prices higher than a vertically integrated (company-owned) firm 
could sustain in the face of competition (e.g., Rey and Stiglitz 1995).

The negative encroachment effects found in this paper, combined with the franchisors' stated reluctance to use territories, imply that franchisors prefer the strategic toughness and higher sales royalty receipts associated with encroachment to the possible higher downstream prices associated with exclusive territories. One explanation is that the sales royalty makes higher downstream prices more unappealing for franchisors than for other types of upstream firms, because sales levels will shrink as the prices increase. Another possibility stems from the empirical regularity that the franchisors very rarely customize contract terms for individual franchisees (Lafontaine and Shaw 1999). They might not be able to increase the sales royalty rates-and thus capture some of the benefit of the high downstream prices occurring within exclusive territories-to offset the lower sales levels also caused by the higher prices.

\subsection{Implications for Policy and Practitioners}

As an increasing number of franchisors find they have exhausted the supply of new domestic markets, they will continue to grow by adding units in markets they already serve. Ongoing channel conflicts with franchisees are inevitable, and franchisees will probably continue to seek legislative and judicial protection against encroachment. However, encroachment does not necessarily signal a need for government intervention. On one hand, the results regarding reduced revenues found here, combined with Conlin's (2003) finding that prices are lower in areas where more units are franchised, suggest that encroachment enhances societal welfare. In addition, the fast growth of the franchised brands has provided consumers with convenience in the form of many locations to choose from. On the other hand, the regularity that franchised hotels appear more likely to be shut down than company-owned hotels (12\% vs. $4.5 \%$ in the 1990s) suggests a detriment to welfare. The difference in failure rates is not consistent with other work, however. Kalnins and Mayer (2004) conducted a hazard rate analysis of pizza restaurant failure and found no difference in failure rates between franchised and company-owned stores.

From the point of view of franchisee welfare, the contracts franchisees signed with seven of the eight franchisors in this study provided no protection from encroachment. If exclusive territories are particularly important to franchisees, the market is able to fill this need. Many franchisors, typically those with less established brands, are very willing to provide franchisees with exclusive territories (Azoulay and Shane 2001). Even after new samebrand units have encroached on an incumbent's mar- ket, the expected value of remaining a franchisee of the brand probably remains positive. Previous work (Kaufmann and Lafontaine 1994, Michael and Moore 1995) has found that franchisors leave substantial rents with franchisees. Encroachment surely reduces these rents, but further operations probably remain viable. Otherwise, it is unlikely that franchisors could consistently recruit new franchisees for their brands.

The results presented here do strongly suggest, however, that franchisees should be skeptical of the claims some franchisors have made to justify encroachment (see, e.g., Sheridan and Gillespie 1995). Franchisors have stated that loss of revenues at existing locations is an unfortunate but unavoidable aspect of expansion. However, the lack of an encroachment effect within expanding company-owned brands implies that encroachment is not merely an unavoidable aspect of growth. Franchisors have also made the argument that if they do not open a unit at a promising location, then one of the other franchisors will. Implicitly evoking the idea of a brand externality, they add that having one of their units will be less disadvantageous to an existing franchisee than a unit of a competitor's brand. The results here also contradict this assertion. Brand conversions and new units of the same brand reduce an incumbent's revenues far more than the entry of other brands of the same quality tier. Finally, potential franchisees should be aware that the "encroachment policies" touted by franchisors have not eliminated the effects of encroachment.

\section{Acknowledgments}

The author thanks Janet Bercovitz, Rob Lowe, Myles Shaver, and Michele Williams for reading previous drafts and making many helpful suggestions. The paper has also benefited from comments made by seminar participants at the 2003 Strategy Research Forum at Washington University, St. Louis; the 2003 Marketing Science conference at the University of Maryland; the 2004 International Society of Franchising, Las Vegas; the 2004 International Industrial Organization Conference, Chicago; and the Boston University Strategy and Policy Seminar Series.

\section{References}

Anderson, E. 1985. The salesperson as outside agent or employee: A transaction cost analysis. Marketing Sci. 4 234-254.

Anderson, E. 1988. Transaction costs as determinants of opportunism in integrated and independent sales forces. J. Econom. Behavior Organ. 9 247-264.

Anselin, L. 1988. Spatial Econometrics: Methods and Models. Kluwer Academic Press, Dordrecht, The Netherlands.

Azoulay, P., S. Shane 2001. Entrepreneurs, contracts, and the failure of young firms. Management Sci. 47 337-358.

Baum, J., H. Haveman. 1997. Love thy neighbor? Differentiation and agglomeration in the Manhattan hotel industry, 1898-1990. Administrative Sci. Quart. 42 304-339. 
Baye, M., K. Crocker, J. Ju. 1996. Divisionalization, franchising, and divestiture incentives in oligopoly. Amer. Econom. Rev. 86 223-236.

Blair, R., F. Lafontaine. 2002. Legislating exclusive territories: Franchising encroachment and legislative proposals. Mimeo, University of Michigan, Ann Arbor, MI.

Brickley, J., F. Dark. 1987. The choice of organizational form: The case of franchising. J. Financial Econom. 17 197-218.

Brickley, J. 1999. Incentive conflicts and contracting: Evidence from franchising. J. Law Econom. 42 745-774.

Chung, W., A. Kalnins. 2001. Agglomeration effects and performance: A test of the Texas lodging industry. Strategic Management J. 22 969-997.

Conlin, M. 2003. The effect of franchising on competition: An empirical analysis. Mimeo, Economics Department, Syracuse University, Syracuse, NY.

Coughlan, A., E. Anderson, L. Stern, A. El-Ansary. 2000. Marketing Channels, 6th ed. Prentice-Hall, Upper Saddle River, NJ.

Darr, E., L. Argote, D. Epple. 1995. The acquisition, transfer, and depreciation of knowledge in service organizations: Productivity in franchises. Management Sci. 41 1750-1762.

Desiraju, R. 2004. Costs and benefits of inducing intrabrand competition: The role of limited liability. Marketing Sci. 23(3) 429-450.

Dutta, S., M. Bergen, G. John. 1994. The governance of exclusive territories: When dealers can bootleg. Marketing Sci. 13 83-99.

Dutta, S., J. Heide, M. Bergen. 1999. Vertical territory restrictions and public policy: Theories and industry evidence. J. Marketing 63 121-134.

Fischer, J., J. Harrington. 1996. Product variety and firm agglomeration. RAND J. Econom. 27 281-309.

Ingram, P., J. Baum. 1997. Chain affiliation and the failure of Manhattan hotels, 1898-1980. Administrative Sci. Quart. 42 68-103.

Jap, S. 1999. Pie-expansion efforts: Collaboration processes in buyersupplier relationships. J. Marketing Res. 36 461-475.

Joskow, A., G. Werden, R. Johnson. 1994. Entry, exit, and performance in airline markets. Internat. J. Indust. Organ. 12 457-471.

Kalnins, A. 2003. Hamburger prices and spatial econometrics. J. Econom. Management Strategy 12 591-616.

Kalnins, A., W. Chung. 2004. Resource-seeking agglomeration: A study of market entry in the lodging industry. Strategic Management J. 25 689-699.

Kalnins, A., F. Lafontaine. 2004. Multi-unit ownership in franchising: Evidence from the fast-food industry in Texas. RAND J. Econom. (Winter).
Kalnins, A., K. Mayer. 2004. Franchising, ownership, and experience: A study of pizza restaurant survival. Management Sci. 50(12).

Kaufmann, P., F. Lafontaine. 1994. Costs of control: The source of economic rents for McDonald's franchisees. J. Law Econom. 37 417-453.

Kaufmann, P., V. Rangan. 1990. A model for managing system conflict during franchise expansion. J. Retailing 66 155-173.

Khanna, T., I. Ganot. 1995. Choice Hotels International 1995, Harvard Case Study \#9-795-165. Harvard Business School Press, Cambridge, MA.

Knott, A. 2001. The dynamic value of hierarchy. Management Sci. 47 430-448.

Lafontaine, F. 1992. Agency theory and franchising: Some empirical results. RAND J. Econom. 23 263-283.

Lafontaine, F., K. Shaw. 1999. The dynamics of franchise contracting: Evidence from panel data. J. Political Econom. 107 1041-1080.

Lal, R. 1990. Improving channel coordination via franchising. Marketing Sci. 9 299-318.

Michael, S., H. Moore. 1995. Returns to franchising. J. Corporate Finance 2 133-156.

Patel, D., J. Corgel. 1995. An analysis of hotel-impact studies. Cornell Hotel Restaurant Administration Quart. 36(4) 27-37.

Rey, P., J. Stiglitz. 1995. The role of exclusive territories in producers' competition. RAND J. Econom. 26 431-451.

Sheridan, M., A. Gillespie. 1995. Hotel industry slows to confront encroachment, financing issues. National Real Estate Investor 37(5) 64-71.

Thomadsen, R. 2004. Price competition in industries with geographic dispersion: Measuring the effect of location on price in the fast food industry. RAND J. Econom. Forthcoming.

Villas-Boas, M. 1998. Product line design for a distribution channel. Marketing Sci. 17 156-169.

Williamson, O. 1991. Comparative economic organization: The analysis of discrete structural alternatives. Administrative Sci. Quart. 36 269-296.

Worcester, B. 1998. Cendant alters franchise-relations policy. Its hotel division has launched a new franchise-relations policy. Hotel Motel Management 213(18) 1-3.

Yin, X., E. Zajac. 2004. The strategy/governance structure fit relationship: Theory and evidence in franchising arrangements. Strategic Management J. 25 365-383. 